\title{
Board Characteristics and Intellectual Capital Performance: A Comparison of Service vs. Manufacturing Firms in India
}

\author{
Dr. G Bharathi Kamath \\ Associate Professor \\ Mumbai School of Economics and Public Policy \\ Ranade Bhavan, Third Floor, University of Mumbai \\ Vidyanagari, Kalina Campus \\ Santacruz (east), Mumbai-400098, India.
}

Biography: The author is currently working as an associate professor in Economics at the University of Mumbai. Intellectual capital measurement, management, disclosure, and intellectual property rights are the major areas of interest. She has published several original research papers in national and international journals in the last decade.

\begin{abstract}
Purpose: This study aims at analysing the board characteristics of select manufacturing and service firms in India. It attempts to explore whether these characteristics influence Intellectual capital (IC) efficiency of service sector firms or manufacturing firms.
\end{abstract}

Design: The study uses panel data and multiple regression to examine the firms' performance. The period of study is three years from 2015-16 to 2017-18; thirty firms each from manufacturing and service sector is taken for study.

Findings: The empirical evidence is quite interesting. The board characteristics of both groups have varied differences. It can also be observed clearly that the impact of board characteristics on IC performance is more in the service sector than in the manufacturing sector.

Research limitations/implications: the study focuses only on select firms from manufacturing and service sector as a preliminary study. The study can be expanded to cover sectors and industries.

Originality and value: There are several research studies that try to explore the impact of corporate governance on the financial performance of firms. However, there are none which looks into their impact on the intangible performance of firms.

Keywords

Intellectual capital, Human capital, Board characteristics, performance, Service sector

Article Classification: Research paper 


\section{Introduction}

More and more firms across the nation are moving towards acknowledging the role of intangibles in value creation. It was a prevalent notion that intangible asset is for only the service sector to measure and manage and manufacturing sectors must focus only on fixed and financial assets. But today it is widely recognized that intangibles or intellectual capital are a business asset for all firms irrespective of the sector they belong to.

Corporate governance ensures the commitment of the board towards their role in increasing and preserving the stakeholder's wealth. The regulator frames guidelines and mandates for the firm's board and monitors it so that there is little deviance from the set path on the part of the directors. The research literature has proved the relationship between the corporate governance characteristics of the firms and their financial performance without any doubt. There are theoretical as well as empirical evidence to support the strong impact which board members impose on the profitability and market valuation of firms. The role of board characteristics on the intangible performance of the firms is yet to be confirmed through robust research results.

Firms face severe competition in the present times and try out innovations product or processes to preserve their competitive advantage over their competitors. In such circumstances, intangibles such as relational capital, human capital and structural capital play an important role in enhancing the firm's competitive edge. The board members have to ensure that they sharpen the firm's ability to compete in the market place. In this context if the relationship between board characteristics is established through empirical evidence, the firms can use the data to strengthen their board and revamp the composition of the board to the optimal level so that it can have a positive impact on the intangible performance of the firms and can contribute towards value-addition in the long run. Thus, the results of the study would not be useful only to the owners of the firm, but also to the policy makers and regulators.

The first section of the paper introduces the concept; this is followed by a review of earlier works in this area. The objective of the paper is spelled out in the next section. A detailed account of the variables used in the study along with data sources and models is presented. This is followed up with results of the study and a detailed analysis of the same. The major conclusions and summary of the findings are put forward in the last section.

\section{Review of Literature}

Hermes et al, 2011 attempt to analyze whether corporate governance practices in different companies result in differences in their performance. They analyzed 124 firms listed on the Athens stock exchange, and find that the performance is positively related to good governance.

Phan and Vo, 2013, took 77 companies listed Vietnam and evaluated whether CG characteristics is useful in improving the financial performance of the firms for a period of 2006-2011. They found that specific factors such as duality, women members on board, their remuneration and also their experience have a positive impact on the profitability. Further, the size of the board has a negative impact on their performance.

Hussein et al, 2012 looked at the impact of CG practices of banks in UAE on financial performance and distress. They discovered that there is a strong positive link between disclosure and transparency of the banks. Protecting shareholders' interests were also seen to be associated with the board of director's characteristics.

Yet another study which focussed on 156 listed firms in Indonesia found that the size of the board has a positive impact on manufacturing firm's performance. They also find that ownership does not have any significant relationship with performance. (Herdjiono and Sari, 2017)

Bhagat and Bolton, 2008 find that CG characteristics and firm's operating performance in the subsequent year is positively related. Board independence and ownership has a positive influence on disciplinary management and turnaround given the poor performance of firms.

As most studies focus on $\mathrm{CG}$ and financial performance, there are few studies that focus on whether board characteristics influence the intangible performance of firms. 
Mahmudi and Nurhayati, 2014 analyzed the banking companies listed on Indonesian stock exchange. They studied the 31 banks for a four year period. Their results proved that there was strong empirical evidence towards a close association between the size of the audit committee, independence of the board and the academic credentials of the board members. They also found that the meetings and audit committee independent members did have no significant impact on IC performance of banks.

Williams, 2001, studied the firms in South Africa to analyze the impact of gender differences and ethnic diversity on IC performance. She found that there is a strong and positive linkage between a number of female directors on board as well as non-white representation on board on IC performance of firms. This evidence helps policymakers to keep the diversity on the basis of race and gender in the board composition.

Yet another study which was placed in the Taiwanese country context, found a strong positive intervening influence of CG characteristics on organizational performance. The researchers used the confirmatory factor analysis (CFA) to study the impact of CG as an intervening variable in the firm's performance. The study was limited to IC designs firms. (Wu, et al, 2012)

Abidin, et al 2009 in their study of firms in Malaysia, found a strong influence of board size on the IC performance of firms. They also reported that for the 75 sample firms of their study, they could not establish any relationship or influence of ownership or CEO duality on performance. The results were considered extremely useful in designing policies to ensure a long term sustainable performance of firms.

Veltri and Mazzotta, 2016 in their study of Italian non- financial firms for a three year period, found that ownership concentration and the board composition both had a positive impact on the profitability of these firms.

There is no study which tries to compare the manufacturing and service sector. The studies related to the impact of CG on IC performance in India does also not exist. Therefore, this study has some specific objectives to fill in the gaps of earlier studies and focus on the impact of board characteristics on IC performance of the firms in the Indian context.

\section{Objectives:}

a. To examine whether Board characteristics of firms have a significant impact on the IC performance in the service sector than manufacturing firms

b. To analyze the Board characteristics of firms in from service and manufacturing.

To systematically evaluate the objectives, it is hypothesized that

H1: Board characteristics, especially board size and its independence have a statistically significant impact on IC performance of firms

H2: Board characteristics vary significantly between firms belonging to the service sector and manufacturing sector.

\section{Research Design:}

3.1. Sample: The study uses firm-level data of 60 firms, equally divided between service sectors and manufacturing sector. The firms are randomly selected from the top 100 firms listed on the Bombay stock exchange. The period of study is 2015-16 to 2017-18. The data required for analysis both in case of dependent and independent for all periods of study is collected from PROWESS database. The data gaps are filled from the annual reports of the firm accessed through www.moneyconrol.com

3.2. Research methods: the data collected is arranged to form a panel, and then analysed using multiple regression. Descriptive statistics of all the variables are also presented to understand the characteristics of the data. The model that is used for the study is presented below in detail followed by a detailed explanation of the dependent and independent variables. 


\subsubsection{Multiple Linear Regression Model:}

Dependent Variable [VAIC, CEE, SCE, or HCE] ${ }_{i t}=\mathrm{a}+\beta_{1} B S I Z E_{i t}+\beta_{2} E X E P_{i t}+\beta_{3} B I N D_{i t}+\beta_{4} B R E_{i t}+\beta_{5} B M E E T_{i t}$ $+\beta_{6} M C A P_{i t}+\beta_{7} L e v_{i t}+\beta_{8} R O A_{i t}+\beta_{9} F A G E_{i t}+\beta_{10} O w n F_{i t}+\varepsilon i$

Where, VAIC = measure of IC efficiency; $C E E_{i}$ is Capital expended efficiency; $H C E_{i}=$ Human capital efficiency;

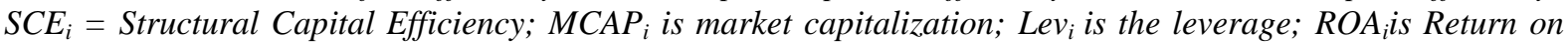
assets; $F A G E_{i}=$ age of the firm; OwnF $F_{i}$ is the ownership of firm; BSIZE $E_{i}$ is the board size; EXEP is $_{i}$ the executive members on board; BIND $D_{i}$ is the number of independent board members; BRE $E_{i}$ is the salary of the board members; BMEET $T_{i}$ is the number of meetings attended by board members and $\varepsilon_{i}=$ residual term. Measurement of all the variables has been described in detail in the above section.

\subsubsection{Explanation of Dependent variables:}

VAIC is the value-added intellectual capital coefficient whose sub-components are Human Capital Efficiency (HCE), Capital Employed Efficiency (CEE) and Efficiency of Structural capital (SCE)

$$
\begin{gathered}
V A I C_{i}=H C E_{i}+C E E_{i}+S C E_{i} \\
\mathrm{CEE}_{\mathrm{i}}=\frac{V A_{i}}{C E_{i}}
\end{gathered}
$$

Capital Employed Efficiency for Firm $\left(\mathrm{CEE}_{\mathrm{i}}\right) ; \mathrm{VA}_{\mathrm{i}}$, Value Added for the firm ${ }_{\mathrm{i}}$; $\mathrm{CE}_{\mathrm{i}}$, book value of the net assets for firm $i$. The VA is measured by using:

$$
V A_{i}=W_{i}+I_{i}+D P_{i}+D_{i}+T_{i}+M_{i}+R_{i}
$$

where $\mathrm{VA}_{\mathrm{i}}$, Value Added for firm i computed as sum of; $\mathrm{I}_{\mathrm{i}}$, interest expense; $\mathrm{DP}_{\mathrm{i}}$, depreciation expenses; $\mathrm{D}_{\mathrm{i}}$, dividends; $\mathrm{T}_{\mathrm{i}}$, corporate taxes; $\mathrm{M}_{\mathrm{i}}$, equity of minority shareholders in net income of subsidiaries; $\mathrm{R}_{\mathrm{i}}$, profits retained for the year.

$$
\mathrm{HCE}_{\mathrm{i}}=\frac{V A_{i}}{H C_{i}}
$$

Human Capital Efficiency for the firm $\mathrm{i}\left(\mathrm{HCE}_{\mathrm{i}}\right) ; \mathrm{VA}_{\mathrm{i}}$, value added for the firm $\mathrm{i} ; \mathrm{HC}_{\mathrm{i}}$, total salary and wage expenditure for the firm $\mathrm{i}$.

$$
\begin{aligned}
& \mathrm{SCE}_{\mathrm{i}}=\frac{S C_{i}}{V A_{i}} \\
& S C_{i}=V A_{i}-H C_{i}
\end{aligned}
$$

Structural Capital for the firm $\mathrm{i}\left(\mathrm{SCE}_{\mathrm{i}}\right)$; $\mathrm{VA}_{\mathrm{i}}$, Value added for the firm $\mathrm{i} ; \mathrm{HC}_{\mathrm{i}}$, total salary and wage expenditure for the firm i.

\subsubsection{Independent variables used in the model:}

Five board characteristics are taken to represent each firm's corporate governance aspects. First and most important is the size of the board, it shows the number of members on the board of each company. Some firms have very large boards and some firms have a two member board. Next is the number of independent members 
on board. Board independence is a very important factor in taking strategic and crucial policy decisions of the firm. A number of executive members on the board is also considered for analysis. The total number of meetings attended by the members is also taken into account for understanding the seriousness of the members towards the firm's policymaking. The total salary of the board members is also an important variable that can influence the IC efficiency of firms.

Besides these factors that reflect the board characteristics, the paper also takes into account the age of the firm and whether the firm is owned by foreign or not. Some characteristics of the firm such as Market capitalization, its debt-equity ratio and its return on assets is used as control variables.

\section{Analysis of Results}

\subsection{Descriptive statistics}

The descriptive statistics for both the dependent and independent variables used in the study are presented in table 1 and table 2 for the service sector and manufacturing sector. The results clearly show that the overall IC efficiency measured in terms of VAIC is higher in service sector firms than in manufacturing firms. Service sector firms on an average have almost more than double IC efficiency than their manufacturing counterparts. The firms in the service sector also fare better in case of human capital efficiency. Whereas, both in case of structural capital efficiency and capital expended efficiency, the manufacturing sector firms show a better performance than service sector firms on an average.

The average board size of manufacturing firms is slightly higher than the firms in the service sector. Both have a similar number of independent members on board. The number of independent members on board of both the group is also comparable. The members of service sector firms attend a higher number of meetings than the manufacturing firm's board members. The firms in the service sector have higher levels of leverage and lower levels of return on their assets when compared to the firms in the manufacturing sector. Thus, we can say that though there are some similarities between the firms in these two groups, they are quite different in many aspects.

\subsection{Analysis of regression results}

As can be seen in Table 3, all four models are statistically significant. This indicates that corporate governance does have an impact on the performance of the firms. It can also be seen that none of the board characteristics are seen to have a statistically significant impact on IC performance of service firms in India. However, it can be seen that the profitability of firms and their leverage does have a positive and significant impact on the intangible efficiency of firms.

In the case of Capital expended efficiency of the firms, it can be seen in the table that the ownership of the service firms has a high impact. The foreign owner ensures that intellectual capital is efficiently utilized. Debt equity ratio and the size of the firm also are important determinants of the capital efficiency of firms. The structural capital efficiency of service firms is heavily determined by board characteristics. Board size has a negative influence on efficiency. Large size boards result in lower efficiency levels of firms. It can also be observed from the results that a large proportion of independent members on board as well as executive members result in an increase in efficiency of these firms. The salary of the board also plays a significant role. As in Human capital efficiency of the service sector, none of the board characteristics influence. It's only the leverage of the firms and their profitability which seem to have an impact on the firm efficiency.

Table 4 presents the results of the models for the manufacturing sector. Here too all four models are statistically significant. However, it can be observed that board characteristics do not influence the overall IC efficiency of firms. Older firms are seen to have a higher IC efficiency. The debt-equity ratio of the manufacturing sector firms, as well as their profitability, also has some influence on their efficiency.

The capital expended efficiency of these firms has a negative influence on the size of the board. Larger boards reduce the CEE sharply. Similarly, greater independence of the directors on board results in a higher level of efficiency of these firms. The larger size of firms and their profitability too impacts the CEE of manufacturing 
sector firms. In the case of Structural efficiency, only independence of the board plays a significant positive role. Human capital efficiency does not depend on any of the board characteristics. Only the age of the firm has a strong impact on the efficiency of these firms. Leverage and profitability of the firms affect both the structural and human capital efficiency of the firms in the manufacturing sector.

\section{Conclusions}

This study was aimed at analyzing the impact of board characteristics on the intellectual capital performance of firms for a three year period. The classification of the firms into the service sector and manufacturing sector enabled the analysis in a systematic way to find out whether board characteristics have a greater influence on the intellectual capital of service or manufacturing sector firms. the board characteristics were represented using board size, number of executive directors, the number of independent directors, and the salary of the board members. The firm's intellectual capital was represented using the VAIC, CEE, HCE, and SCE.

The results of the study provide clear evidence that board characteristics, especially board size and its independence have a strong and statistically significant impact on the service sector firms IC performance. The impact of board characteristics also has an impact on various sub-components of intellectual capital. This study paves the way for future studies in this area. Studying the impact on specific industries would help frame policies that are relevant to the specific segments. The country comparisons would be possible if uniform sets of firms are analyzed across industries and nations. The policy makers can take the preliminary information derived from the empirical results of this study to frame fruitful policies which will prove to be beneficial for increasing the overall shareholder's value and wealth.

\section{References}

[1]. Abhayawansa, S. and Guthrie, J., 2014. Importance of intellectual capital information: a study of Australian analyst reports. Australian Accounting Review, 24(1), 66-83.

[2]. Abidin, Z. Z., Kamal, N. M., \&Jusoff, K. (2009). Board structure and corporate performance in Malaysia. International Journal of Economics and Finance, 1(1), 150-164.

[3]. Ante, Pulic, (2001), "Value Creation Efficiency Analysis of Croatian Banks 1996-2000", accessed in March 2013 available onhttp://www.vaic-on.net/

[4]. Ante, Pulic, (2002), "Do we know if we create or destroy value?", accessed in March 2013, available on http://www.vaic-on.net

[5]. Bhagat, S., \& Bolton, B. (2008). Corporate governance and firm performance. Journal of corporate finance, 14(3), 257-273.

[6]. Bontis, N. (1998), "Intellectual capital: an explanatory study that develops measures and models", Management Decision, 36 (2), 63-76.

[7]. Duc, V. H., \& Thuy, P. B. G. (2013). Corporate governance and firm's performance: empirical evidence from Vietnam. Journal of Economic Development, (JED, No. 218), 62-77.

[8]. Herdjiono, I., \& Sari, I. M. (2017). The effect of corporate governance on the performance of a company. Some empirical findings from Indonesia. Journal of Management and Business Administration, 25(1), 33-52.

[9]. Hermes, Niels and Katsigianni, Vasiliki, Corporate Governance and Company Performance: Evidence from Greece (January 6, 2011). Available SSRN: https://ssrn.com/abstract=1980331 or http://dx.doi.org/10.2139/ssrn.1980331

[10]. Hussein A. Hassan Al, Tamimi, (2012) "The effects of corporate governance on performance and financial distress: The experience of UAE national banks", Journal of Financial Regulation and Compliance, 20(2), 169-181

[11]. Kamath, G. B., (2008), "Intellectual capital and corporate performance in Indian pharmaceutical industry", Journal of Intellectual Capital, 9(4), 684 - 704.

[12]. Keenan, J., and Aggestam, M., (2001) Corporate governance and intellectual capital: some conceptualisations. Corporate Governance: An International Review 9(4), 259-275.

[13]. Mahmudi, B., \&Nurhayati, E. (2015). The Influence of Board Governance Characteristics on Intellectual Capital Performance (Empirical Study on Listed Banks in BEI 2008-2012). Review of Integrative Business and Economics Research, 4(1), 417.

[14]. Makki, M. A. M., and Lodhi, S. A., (2014) Impact of Corporate Governance on Intellectual Capital Efficiency and Financial Performance. Pakistan Journal of Commerce and Social Sciences 8(2), 305330. 
[15]. Veltri, S., and R. Mazzotta. 2016. The association of board composition, intellectual capital and firm performance in a high ownership concentration context: Evidence from Italy. InternationalJournal of Business and Management 11(10), 317-331.

[16]. Williams, S. M. (2001). Corporate governance diversity and its impact on intellectual capital performance in an emerging economy. The University of Calgary, Faculty of Management.

[17]. Wu, M. F., Lee, Y. J., \& Wang, G. L. (2012). To verify how intellectual capital affects organizational performance in listed Taiwan IC design companies with considering the moderator of corporate governance. Journal of Global Business Management, 8(1), 20. 
Table 1: Descriptive Statistics of all variables- Service Sectors

\begin{tabular}{|l|c|c|}
\hline Variables & \multicolumn{1}{|l|}{ Mean } & Standard Deviation \\
\hline VAIC & 14.336 & 24.244 \\
\hline SCE & 0.0535 & 2.3764 \\
\hline HEE & 0.4031 & 1.1682 \\
\hline Board Size & 13.987 & 23.969 \\
\hline Independent directors & 11.879 & 2.815 \\
\hline Executive directors & 5.803 & 2.0507 \\
\hline Meetings attended & 1.7736 & 2.2223 \\
\hline Salary (Log) & 71.258 & 36.41 \\
\hline MCAP (log) & 18.035 & 1.5093 \\
\hline Leverage & 12.779 & 1.2665 \\
\hline ROA & 2.1477 & 2.3974 \\
\hline
\end{tabular}


Table 2: Descriptive Statistics of all variables- Manufacturing Sectors

\begin{tabular}{|l|c|c|}
\hline Variables & \multicolumn{1}{|l|}{ Mean } & Standard Deviation \\
\hline VAIC & 6.1862 & 3.8795 \\
\hline SCE & 0.61989 & 0.65805 \\
\hline HCE & 0.75654 & 0.8006 \\
\hline Board Size & 4.8098 & 3.8089 \\
\hline Independent directors & 12.471 & 3.0566 \\
\hline Executive directors & 5.9608 & 1.7163 \\
\hline Meetings attended & 2.1915 & 2.4718 \\
\hline Salary (Log) & 62.353 & 27.18 \\
\hline MCAP (log) & 18.843 & 1.0883 \\
\hline Leverage & 12.706 & 1.1094 \\
\hline ROA & 1.0867 & 9.3132 \\
\hline
\end{tabular}


Table 3: Results of Multiple Regression-Service Sectors (2015-16 to 2017-18)

\begin{tabular}{|c|c|c|c|c|c|c|c|c|}
\hline $\begin{array}{l}\text { Dependent } \\
\text { Variables }\end{array}$ & \multicolumn{2}{|c|}{ VAIC } & \multicolumn{2}{|c|}{$\overline{C E E}$} & \multicolumn{2}{|c|}{$\overline{S C E}$} & \multicolumn{2}{|c|}{$\overline{\mathrm{HCE}}$} \\
\hline $\mathrm{N}$ & \multicolumn{2}{|c|}{30} & \multicolumn{2}{|c|}{30} & \multicolumn{2}{|c|}{30} & \multicolumn{2}{|c|}{30} \\
\hline Adjusted $\mathrm{R}^{2}$ & \multicolumn{2}{|c|}{0.211} & \multicolumn{2}{|c|}{0.622} & \multicolumn{2}{|c|}{0.414} & \multicolumn{2}{|c|}{0.202} \\
\hline F statistic & \multicolumn{2}{|c|}{2.573} & \multicolumn{2}{|c|}{15.828} & \multicolumn{2}{|c|}{6.790} & \multicolumn{2}{|c|}{2.437} \\
\hline p-value & \multicolumn{2}{|c|}{0.004} & \multicolumn{2}{|c|}{0.000} & \multicolumn{2}{|c|}{0.000} & \multicolumn{2}{|c|}{0.007} \\
\hline & & $t$-value & & $t$-value & & $t$-value & & $t$-value \\
\hline Intercept & 30.074 & 0.750 & $5.687 * * *$ & 4.242 & -2.529 & -0.953 & 26.915 & 0.672 \\
\hline $\begin{array}{c}\text { Explanatory } \\
\text { Variables }\end{array}$ & Beta & & Beta & & Beta & & Beta & \\
\hline Board Size & -0.704 & -0.748 & -0.048 & -1.551 & -0.050 & -0.818 & -0.605 & -0.644 \\
\hline $\begin{array}{l}\text { Independent } \\
\text { Directors }\end{array}$ & 3.021 & 0.169 & 0.663 & 1.114 & $2.050^{*}$ & 1.738 & 4.407 & 0.247 \\
\hline $\begin{array}{l}\text { Executive } \\
\text { Directors }\end{array}$ & -0.911 & -0.468 & 0.038 & 0.598 & $0.553 * * *$ & 4.300 & -0.397 & -0.204 \\
\hline Board Salary & -0.322 & -0.177 & 0.047 & 0.782 & $0.405 * * *$ & 3.362 & -0.775 & -0.426 \\
\hline Meetings attended & -1.420 & -1.019 & 0.017 & 0.374 & -0.116 & -1.262 & -1.321 & -0.950 \\
\hline Age & 3.463 & 0.698 & -0.273 & -1.65 & $0.800 * *$ & 2.439 & 2.937 & 0.593 \\
\hline Ownership(F) & -6.143 & -0.5050 & $1.090 * * *$ & 2.682 & -0.471 & -0.586 & -6.762 & -0.556 \\
\hline $\begin{array}{c}\text { Control } \\
\text { Variables }\end{array}$ & & & & & & & & \\
\hline MCap & -0.154 & -0.050 & $-0.527 * * *$ & -5.146 & -0.209 & -1.033 & 0.583 & 0.19 \\
\hline Lev & $3.585 * * *$ & 3.702 & $0.061 *$ & 1.889 & $0.149 * *$ & 2.331 & $3.375 * * *$ & 3.492 \\
\hline ROA & $0.626^{* *}$ & 2.616 & 0.074 & 9.37 & 0.012 & 0.759 & $0.539 * *$ & 2.257 \\
\hline
\end{tabular}


Table 4: Results of Multiple Regression- Manufacturing Sector (2015-16 to 2017-18)

\begin{tabular}{|c|c|c|c|c|c|c|c|c|}
\hline $\begin{array}{c}\text { Dependent } \\
\text { Variables }\end{array}$ & \multicolumn{2}{|c|}{ VAIC } & \multicolumn{2}{|c|}{ CEE } & \multicolumn{2}{|c|}{ SCE } & \multicolumn{2}{|c|}{ HCE } \\
\hline $\mathrm{N}$ & \multicolumn{2}{|c|}{30} & \multicolumn{2}{|c|}{30} & \multicolumn{2}{|c|}{30} & \multicolumn{2}{|c|}{30} \\
\hline Adjusted $\mathrm{R}^{2}$ & \multicolumn{2}{|c|}{0.180} & \multicolumn{2}{|c|}{0.153} & \multicolumn{2}{|c|}{0.300} & \multicolumn{2}{|c|}{0.169} \\
\hline F statistic & \multicolumn{2}{|c|}{2.568} & \multicolumn{2}{|c|}{2.117} & \multicolumn{2}{|c|}{5.022} & \multicolumn{2}{|c|}{2.376} \\
\hline p-value & \multicolumn{2}{|c|}{0.004} & \multicolumn{2}{|c|}{0.019} & \multicolumn{2}{|c|}{0.000} & \multicolumn{2}{|c|}{0.008} \\
\hline & & $t$-value & & $t$-value & & $t$-value & & $t$-value \\
\hline Intercept & -2.977 & -0.388 & -0.892 & -0.554 & 0.838 & 0.697 & -2.923 & -0.385 \\
\hline $\begin{array}{c}\text { Explanatory } \\
\text { Variables }\end{array}$ & Beta & & Beta & & Beta & & Beta & \\
\hline Board Size & -0.082 & -0.680 & $-0.052 * *$ & -2.075 & -0.009 & -0.512 & -0.020 & -0.167 \\
\hline $\begin{array}{l}\text { Independent } \\
\text { Directors }\end{array}$ & -3.976 & -1.237 & $1.343^{* *}$ & 1.994 & $0.8200 *$ & 1.739 & -4.499 & -1.417 \\
\hline $\begin{array}{l}\text { Executive } \\
\text { Directors }\end{array}$ & 0.0349 & 0.152 & 0.066 & 1.377 & -0.043 & -1.213 & 0.012 & 0.054 \\
\hline Board Salary & 0.162 & 0.445 & -0.076 & -0.998 & -0.006 & -0.110 & 0.245 & 0.68 \\
\hline Meetings attended & 0.202 & 0.778 & 0.057 & 1.062 & 0.02051 & 0.502 & 0.124 & 0.482 \\
\hline Age & $2.164 * *$ & 2.524 & 0.063 & 0.35 & -0.025 & -0.192 & $2.127 * *$ & 2.51 \\
\hline Ownership(F) & 0.333 & 0.403 & 0.183 & 1.058 & 0.034 & 0.265 & 0.115 & 0.141 \\
\hline Control Variables & & & & & & & & \\
\hline MCap & 0.483 & 1.121 & $0.185 * *$ & 2.054 & 0.013 & 0.204 & 0.283 & 0.665 \\
\hline Leverage & $1.401 * * *$ & 3.509 & 0.131 & 1.573 & $-0.150 * *$ & -2.399 & $1.419 * * *$ & 3.597 \\
\hline $\mathrm{ROA}$ & $0.173 * * *$ & 3.56 & $0.019^{*}$ & 1.886 & $0.014 *$ & 1.964 & $0.139 * * *$ & 2.89 \\
\hline
\end{tabular}

